\title{
THE STUDY OF ANTIFUNGAL ACTIVITY FROM INDIGENOUS PLANTS FROM INDONESIA: AN IN VITRO STUDY
}

\author{
ELIN YULINAH SUKANDAR*a, IRDA FIDRIANNY ${ }^{\mathrm{b}}$, ERIWAN SUSANTO $^{\mathrm{a}}$, DEWI SAFITRI ${ }^{\mathrm{a}}$
}

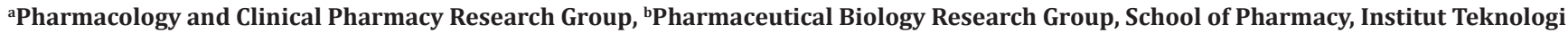
Bandung, Gedung Yusuf Panigoro, Jalan Ganesha, No. 10, Bandung 40132, West Java, Indonesia. Email: elin@fa.itb.ac.id

Received: 23 August 2016, Revised and Accepted: 10 October 2016

\section{ABSTRACT}

Objective: This study aimed to analyze new agents from extracted Indonesia herbs possessing antifungal activity with better safety profile against Candida albicans, Microsporum gypseum, and Trichophyton mentagrophytes.

Methods: The screening of 11 herbs was performed to determine the highest antifungal activity. Minimum inhibitory concentration and minimum fungicidal concentration of selected extracts, rosemary (Rosmarinus officinalis) leaves, java turmeric (Curcuma xanthorrhiza) rhizome, and ginger (Zingiber officinale) rhizome were determined using microdilution and agar diffusion methods. Extracts were then combined to evaluate further activities. Selected extracts were fractionated using liquid-liquid extraction, analyzed by thin-layer chromatography-direct (TLC) bioautography.

Results: Ethanolic extract of rosemary ( $R$. officinalis) leaves, java turmeric ( $C$. xanthorrihza) rhizome, and ginger ( $Z$. officinalis) rhizome in combination showed the highest activity and synergistic interaction against Trichophyton mentagrophytes. There were several components from fractions that actively inhibited corresponding fungi according to TLC bioautography method.

Conclusion: Ethanolic extracts of rosemary, java turmeric, and ginger had the highest antifungal potency, both as extract and in combination comparable to ketoconazole as reference drug. These selected extracts are potential to be used as new antifungal agents.

Keywords: Antifungal, Rosemary, Ginger, Java turmeric, In situ, Bioautography thin-layer chromatography-direct.

(C) 2017 The Authors. Published by Innovare Academic Sciences Pvt Ltd. This is an open access article under the CC BY license (http://creativecommons. org/licenses/by/4. 0/) DOI: http://dx.doi.org/10.22159/ajpcr.2017.v10i1.14838

\section{INTRODUCTION}

Being located in tropical area causes high prevalence of fungal infection due to high level of humidity and temperature. For instance, the percentage of skin infection which is caused by fungi in Indonesia is relatively high. It can be seen in one hospital in Indonesia: Adam Malik Hospital and Pirngadi Hospital in Medan, cutaneous fungal infection is the second highest skin disorders in the hospitals. In 2002, dermatophytosis case was the highest prevalence compared to other skin disorders [1].

Dermatophytosis is a typical disease caused by dermatophyta colonization in skin layers including stratum corneum, hair, and nails. These kinds of fungi have abilities to bind with keratin and utilize it as an energy source to form colonization [2]. In Indonesia, dermatophytosis is the highest incidence in the group of superficial dermatomycosis [2]. According to former research conducted in 1980 in Dr. Cipto Mangunkusumo Hospital, Jakarta, the most common fungus causes dermatophytosis is Trichophyton rubrum [3]. Other factors such as age, gender, and ethnic play important roles as epidemiological factors and lead to a higher incidence of cutaneous fungal infection both in male than female patients, with approximately five times higher [2] in male patients. Regions, individual hygiene, and economic status also play a role on spreading the infection.

Lots of medicinal agents have been developed since thousands years ago and numerous modern medicine are derived from natural products [4]. In Indonesia, indigenous people have been using herbs as alternative agents for ailments, as preventive, curative, rehabilitative, and promotive agents. There is a lot of herb in Indonesia such as Java turmeric rhizome, ginger rhizome, rosemary leaves, sembung leaves, kelor leaves, beluntas leaves, lengkeng leaves, kelor seed, kemangi leaves, bungur leaves, and ketepeng cina that are utilized as agents in treating cutaneous fungal infection. This study then was performed to complete previously conducted research in observing anti-fungal activity of such herbs through in vitro assay.

\section{METHODS}

\section{Materials and fungal strains}

Eleven herbs collected including Java turmeric rhizome, ginger rhizome, rosemary leaves, sembung leaves, kelor leaves, beluntas leaves, lengkeng leaves, kelor seed, kemangi leaves, bungur leaves, and ketepeng cina were collected from several areas in West Java, Indonesia, starting from January to April and determined at Herbarium Bandungense, School of Life Science and Technology, Indonesia. The fungi that were used in this study included Candida albicans, T. mentagrophytes, and Microsporum gypseum. All of them were provided from Microbiology Laboratory, School of Pharmacy, Institut Teknologi Bandung, Indonesia. The fungi were maintained under standard condition on sabouraud dextrose agar (SDA). Inoculum of $C$. albicans was incubated in $28^{\circ} \mathrm{C}$ for a whole day; meanwhile, T. meganthrophytes and M. gypseum were kept for 7 days.

Preparation, standardization, and phytochemical screening of extracts

Herbs dried in the oven were pulverized into powder. It was extracted with ethanol 96\%, three times repeatedly, using reflux method. Subsequently, each extract was concentrated in a rotary evaporator until viscous form was obtained and they were kept at $4{ }^{\circ} \mathrm{C}$ for further analysis. Standardization was performed on both crude materials and extracts regarding quality control published by the WHO [5]. Qualitative phytochemical screening included alkaloid, flavonoid, saponin, quinone, tannin, and steroid/triterpenoid. 


\section{Culture media and tested extract preparation}

Media

SDA and sabouraud dextrose broth (SDB) were utilized in this study. Approximately $65 \mathrm{~g}$ of SDA was mixed in $1 \mathrm{~L}$ distilled water whereas $30 \mathrm{~g}$ SDB was solved in the same amount of distilled water. Before experiment, both media were sterilized by autoclaving at $121^{\circ} \mathrm{C}$ for 15 minutes [6], each solution was boiled for about 1 minute.

\section{Tested extract}

Each viscous extract (1638.4 mg) was dissolved in $10 \mathrm{~mL}$ dimethyl sulfoxide (DMSO) $100 \%$ as stock solution. This solution was used to make a working solution of $16.384 \mu \mathrm{g} / \mathrm{mL}$ in DMSO $10 \%$ after dilution using SDB. Ketoconazole was used as reference drug. About $25.6 \mathrm{mg}$ ketoconazole was dissolved in $10 \mathrm{~mL}$ of DMSO $100 \%$, and it was diluted into $256 \mu \mathrm{g} / \mathrm{mL}$ in DMSO 10\%, after diluting by SDB.

\section{Preparation of inocula for microdilution assay}

C. albicans

Inocula $24 \mathrm{hrs}$ of $C$. albicans were suspended in sterile $\mathrm{NaCl} 0.85 \%$, following the 0.5 McFarland turbidity to obtain a concentration of approximately $1 \times 10^{6}-5 \times 10^{6} \mathrm{CFU} / \mathrm{mL}$ by standardization of optical density using ultraviolet (UV)/visible spectrophotometer at $625 \mathrm{~nm}$ (absorbance value is between 0.08 and 0.10) [7]. Sterile $\mathrm{NaCl} 0.85 \%$ was used as the blank solution. Working suspension for microdilution method was made by diluting corresponding inoculum 50 and 20 times using SDB media [8].

T. mentagrophytes and M. gypseum. A-7-day-inoculum of M. gypseum and T. mentagrophytes were suspended in sterile $\mathrm{NaCl} 0.85 \%$. Standardization was conducted by adjusting turbidity in the range of $70-72 \%$ at $520 \mathrm{~nm}$. Sterile $\mathrm{NaCl} 0.85 \%$ was used as blank. This inoculum was then diluted 50 times using SDB media for further experiment as working suspension [9]

Determination of minimum inhibitory concentration (MIC) and minimum fungicidal concentration (MFC) by microdilution assay MIC and MFC were carried out using 96-well-microplate according to NCCL M27-A3 guidelines (CLSI M27-A3). Each well was inoculated with $100 \mu \mathrm{l}$ of SDB. The first and second wells were placed as control negative (200 $\mu \mathrm{l} \mathrm{SDB}$, uninoculated-drug-free medium) and growth control (100 $\mu \mathrm{l}$ SDB and $100 \mu \mathrm{l}$ corresponding inocula), respectively. In the last well, $100 \mu \mathrm{l}$ of ketoconazole or extract was added and was mixed gently. From this well, a series of dilution was performed to the final desired concentration on the third well. This microwell plate was placed into $28^{\circ} \mathrm{C}$ incubator for certain period. The lowest concentration without any growth was considerably determined as MIC. Around $5 \mu \mathrm{l}$ aliquot from every single clear-well was taken to be propagated in the solid medium. The minimum concentration in without visible fungal growth was classified as MFC [8-10].

\section{Determination of type of antifungal combination Checkerboard assay}

The microdilution checkerboard was a traditional method for the measurement of antibiotic interaction [11]. In brief, the protocol was similar to that of microdilution method by which final concentration of extract set up to be different. First, for 2 extracts in combination, a double MIC of each extract was mixed together as master solution. This solution was then diluted subsequently 2 times to obtain final concentration equal to MIC, $1 / 2$ MIC, $1 / 4$ MIC, and 1/8 MIC for each extract. Meanwhile, for a 3-extract-combination, it was made by combined 4/3 MIC from each extract. It was diluted to obtain final concentration equal to 4/3 MIC, 2/3 MIC, 1/3 MIC, 1/6 MIC, and 1/12 MIC. The characteristic of antibiotic combination was expressed as fractional inhibitory concentration (FIC). FIC index of $<1$ indicates a synergistic interaction between two antibiotics. FIC index which is equal to 1 represents additive interaction while a FIC index of $>1$ indicates antagonistic interaction between two antibiotics.
Paper strip assay

About 15 mL SDA which was previously inoculated with fungi was filled in petri dish. Two or three filter papers were soaked in each extract and mount onto the agar making intersect each other.

\section{Paper discs assay}

Two or three discs were placed close enough between the disc to determine area of interaction. Then, $10 \mu \mathrm{l}$ of extract was dripped onto the paper disc. Each petri dish was incubated at $28^{\circ} \mathrm{C}$ for a day for C. albicans and 5-7 days for T. mentagrophytes and M. gypseum. Clear area around paper disc was measured as inhibitory zone.

\section{Determination equivalence potency of tested substances}

Paper disc assay was utilized in this study to determine equivalence potency of extract toward ketoconazole as reference drug. A series of concentration of extracts and a comparison were made using ethanol $96 \%$.

A total of $15 \mathrm{~mL}$ of SDA which was already inoculated with tested fungi was placed into petri dish and allowed to become solid. Six pieces of sterile paper disk were placed on the surface of agar medium. Approximately $10 \mu \mathrm{l}$ of extract or reference drug was dripped into each disc. Then, the petri dishes were incubated at $28^{\circ} \mathrm{C}$ for 1 day for C. albicans and 5-7 days T. mentagrophytes and M. gypseum. Inhibitory zone around paper disk was measured and recorded appropriately. To calculate equality toward reference drug, linear regression line was made into logarithmic curve versus diameter of inhibitory zone.

\section{Bioautography thin-layer chromatography (TLC)}

Bioautography TLC was performed by placing the chromatogram of extract, fraction, or subfraction onto the surface of inocula. Chromatogram was exposed for approximately 30-60 minutes to ensure diffusion of compounds contained in chromatogram [12].

\section{RESULTS AND DISCUSSION}

Standardization and phytochemical screening

Medicinal herbs are essential of resource as it may contain active compounds which is able to be investigated in drug development [13]. Lots of medicinal herbs which are used empirically in certain sites have been researched to analyze alternative agents for treating diseases, such as fungal infection. There is only a few agents to treat such an infection. Thus, based on our previous research and ethnopharmacological studies, we are trying to observe the antifungal activity of eleven selected herbs from Indonesia.

Eleven herbs were harvested from over the West Java region in certain period. Selection of herbs was determined according to empirical utilization by indigenous people in Indonesia and our previous research related to antifungal activities of those eleven herbs. Each plant was collected from particular area to minimize variation of metabolites due to location. There are several factors affecting metabolites contained in plants, such as location, altitude, climate change [14], temperature, and rain level. Concentration of metabolites, particularly secondary metabolites, seems to be contribute to the pharmacological effect.

Among all herbs, there were only rosemary (Rosmarinus officinalis) leaves, ginger (Zingiber officinale) rhizome, and Java turmeric (Curcuma xanthorrhiza) rhizome being extracted by ethanol showed the highest potency against $C$. albicans, T. mentagrophytes, and M. gypseum. Antifungal activity of all extracts is described in Table 1 . Thus, for further examination, discussion would be focused on these selected extracts.

Previous research stated that rosemary (R. officinalis) leaves contained polyphenol compounds, with majority of carnosic acid, carnosol, 12-0-methylcarnosic acid (phenolic diterpenes), rosmarinic acid (caffeoyl compound), genkwanin and isoscutellarein 7-0-glucoside (flavones) [15]. Almost of all compounds mentioned are classified as phenolic compound which exist in the phytochemical screening conducted in this study. We did not isolate active compounds in this 
study, but we separated organic compound which inhibited fungi growth using bioautography assay, later in this paper.

Valera et al. mentioned in their paper that certain compounds from ginger (Zingiber officinale) were able to demonstrate synergistic effect on endodontic procedure as auxiliary chemical medication against C. albicans, Enterococcus faecalis, Escherichia coli, and their endotoxins [16] and also other microbes [17], which means component in ginger have antimicrobial activity. Many antioxidant compounds exist in ginger rhizome leading to broad range pharmacological effect, such as improving lipid profile [18], inhibiting platelet aggregation [19], ameliorating renal and pancreas damage [20], having analgesic effect [21], inhibiting melanoma [22], improving glucose uptake [23], and many other effects.

Java turmeric or widely known as Java turmeric (Curcuma xanthorrhiza) contains curcuminoid and xanthorrhizol as major constituents. It also has lots of essential oil, such as terpenoid, phenolic compounds, saponin, cardiac glycoside, anthraquinone, anthrone, tannin, and coumarin [24]. Hwang reported that polysaccharide from $C$. xanthorrhiza was able to stimulate immune system; therefore, it is useful as alternative agent for immunomodulator [25].

Standardization is an important parameter to ensure relevance between contained matters in the herbs and its pharmacological activities. For standardization, TLC was performed using silica gel GF254, followed by organic compound monitored by spraying $\mathrm{H}_{2} \mathrm{SO}_{4} 10 \%$ in methanol, observed under UV light $254 \mathrm{~nm}$ and $366 \mathrm{~nm}$. The chromatogram is depicted in Fig. 1.

MIC and MFC of extracts: Microdilution and agar diffusion methods Utilizing sterilized 96 round bottom microwell plate, approximately $0.5-2.5 \times 10^{3} \mathrm{CFU} / \mathrm{mL}$ suspension of $C$. albicans and $0.4-5 \times 10^{4} \mathrm{CFU} / \mathrm{mL}$

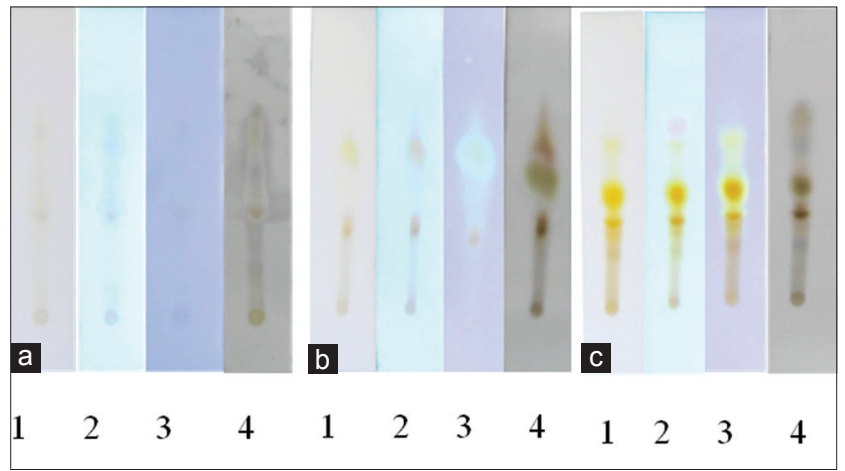

Fig. 1: Chromatogram of rosemary leaves extract, using silica gel GF254 as stationary phase, chloroform and methanol (13:1) in combination were utilized as mobile phase with additional

4 drops of acetic acid. (1) Under visible light, (2) ultraviolet (UV)-light $\lambda 254 \mathrm{~nm}$, (3) UV-light $\lambda 366 \mathrm{~nm}$, and (4) after spraying by $\mathrm{H} 2 \mathrm{SO} 4 \mathrm{10} \%$ in methanol. (a) Rosemary leaves' extract, (b) ginger rhizome extract, (c) java turmeric extract for T. mentagrophytes and M. gypseum were prepared. According to NCCLS, ketoconazole as reference drug was used between 0.03125 and $16 \mu \mathrm{g} / \mathrm{mL}$. However, in this research, the concentration of ketoconazole was between 0.5 and $256 \mu \mathrm{g} / \mathrm{mL}$, according to that of orientation.

Microdilution method in this study was a modified version from the CLSI method. Instead of using SDB, we utilized Roswell Park Memorial Institute (RPMI). According to our previous research, there was no significant difference between RPMI and SDB. Using SDB, the range of concentration was relatively wider than RPMI media. Nevertheless, SDB provides several advantages compared to RPMI, including more economic and autoclavable whereas RPMI should be sterilized by filtration which is less practical. Results of MIC and MFC of all extracts are presented in Table 2 . Tables 3 and 4 represent the results of antifungal activity using an agar diffusion method.

The study on antifungal activity of selected extracts in combination To observe antifungal effect of three selected extracts, checkerboard assay and agar diffusion using filter paper as well as filter paper were used [26]. The result is shown in Tables 5 and 6, Fig. 2.

Table 1: Results of crude herbs and standardization of ethanolic extracts of rosemary leaves, ginger rhizome, and java turmeric rhizome

\begin{tabular}{|c|c|c|c|}
\hline \multirow[t]{2}{*}{ Parameters } & \multicolumn{3}{|l|}{ Result } \\
\hline & Rosemary & Ginger & $\begin{array}{l}\text { Java } \\
\text { turmeric }\end{array}$ \\
\hline \multicolumn{4}{|l|}{ Crude herbs } \\
\hline Volatile matter $(\% \mathrm{w} / \mathrm{w})$ & 7.95 & 16.74 & 18.07 \\
\hline Total ash content (\%w/w) & 4.96 & 5.53 & 5.73 \\
\hline Alkaloid & - & - & - \\
\hline Flavonoid & + & + & + \\
\hline Tannin & - & - & - \\
\hline Phenol & + & + & + \\
\hline Saponin & - & - & - \\
\hline Quinone & + & + & + \\
\hline Steroid/triterpenoid & + & + & + \\
\hline \multicolumn{4}{|l|}{ Extract } \\
\hline Water content $(\% \mathrm{v} / \mathrm{w})$ & 15.00 & 9.00 & 11.00 \\
\hline Volatile matter & 23.54 & 12.24 & 14.16 \\
\hline $\begin{array}{l}\text { Extractable matter in } \\
\text { water }(\% \mathrm{w} / \mathrm{w})\end{array}$ & 5.28 & 11.85 & 9.23 \\
\hline $\begin{array}{l}\text { Extractable matter in } \\
\text { ethanol }(\% \mathrm{w} / \mathrm{w})\end{array}$ & 15.27 & 59.48 & 64.55 \\
\hline Specific gravity $(\mathrm{g} / \mathrm{mL})$ & $\mathrm{N} / \mathrm{A}$ & 1.18 & 1.22 \\
\hline Extract yield (\%w/w) & 26.41 & 15.47 & 22.35 \\
\hline Alkaloid & - & - & - \\
\hline Flavonoid & + & + & + \\
\hline Tannin & - & - & - \\
\hline Phenol & + & + & + \\
\hline Saponin & - & - & - \\
\hline Quinone & + & + & + \\
\hline Steroid/triterpenoid & + & + & + \\
\hline
\end{tabular}

+: Means detectable, -: Undetectable

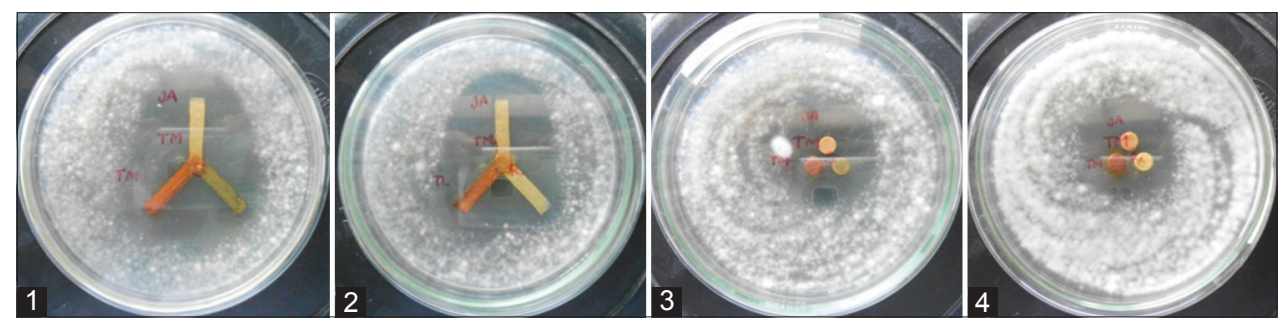

Fig. 2: Results of interaction of extracts using filter paper-agar diffusion method (1 and 2); using disc paper (3 and 4 ). (1 and 3 ) ethanolic ginger extract, sembung leaves, and Java turmeric rhizome, ( 2 and 4 ) ethanolic extract of ginger rhizome, rosemary leaves, and Java turmeric rhizome 
Table 2: MIC and MFC of ethanolic extracts of eleven herbs against Candida albicans, Trichophyton mentagrophytes, dan Microsporum gypseum

\begin{tabular}{|c|c|c|c|c|c|c|}
\hline \multirow{2}{*}{$\begin{array}{l}\text { Fungi } \\
\text { Plants }\end{array}$} & \multicolumn{2}{|c|}{ Candida albicans } & \multicolumn{2}{|c|}{ Trichophyton mentagrophytes } & \multicolumn{2}{|c|}{ Microsporum gypseum } \\
\hline & $\operatorname{MIC}(\mu \mathrm{g} / \mathrm{mL})$ & MFC $(\mu \mathrm{g} / \mathrm{mL})$ & MIC $(\mu \mathrm{g} / \mathrm{mL})$ & MFC $(\mu \mathrm{g} / \mathrm{mL})$ & MIC $(\mu \mathrm{g} / \mathrm{mL})$ & MFC $(\mu \mathrm{g} / \mathrm{mL})$ \\
\hline Kelor leaves & - & - & - & - & - & - \\
\hline Java turmeric rhizome & - & - & 128 & 1024 & 128 & 1024 \\
\hline Kemangi leaves & - & - & - & - & - & - \\
\hline Lengkeng leaves & - & - & 2048 & $>4096$ & 2048 & $>4096$ \\
\hline Ginger rhizome & - & - & 64 & 512 & 128 & 1024 \\
\hline Rosemary leaves & - & - & 256 & 2048 & 512 & 2048 \\
\hline Sembung leaves & - & - & 512 & 4096 & 1024 & $>4096$ \\
\hline Ketepeng cina leaves & - & - & - & - & - & - \\
\hline Kelor seed & - & - & - & - & - & - \\
\hline Beluntas seed & - & - & 1024 & 4096 & 1024 & $>4096$ \\
\hline Bungur leaves & - & - & - & - & - & - \\
\hline Ketoconazole & 1 & 4 & 32 & 64 & 32 & 128 \\
\hline
\end{tabular}

-: MIC and MFC are undetermined although the highest concentration was used. MIC: Minimum inhibitory concentration, MFC: Minimum fungicidal concentration

Table 3: Diameter of inhibitory zone from all extracts against Trichophyton mentagrophytes

\begin{tabular}{lllll}
\hline \multirow{2}{*}{ Extract } & \multicolumn{4}{l}{ Inhibitory zone $(\mathbf{m m})$} \\
\cline { 2 - 5 } & $\mathbf{2 \%}$ & $\mathbf{4 \%}$ & $\mathbf{6 \%}$ & $\mathbf{8 \%}$ \\
\hline Rosemary & $9.63 \pm 0.32$ & $11.17 \pm 0.21$ & $13.20 \pm 0.27$ & $14.60 \pm 0.27$ \\
Java turmeric & $12.50 \pm 0.20$ & $14.00 \pm 0.36$ & $16.40 \pm 0.10$ & $16.93 \pm 0.15$ \\
Beluntas & $7.30 \pm 0.27$ & $8.40 \pm 0.27$ & $9.33 \pm 0.25$ & $9.90 \pm 0.1$ \\
Lengkeng & - & - & $7.87 \pm 0.25$ & $8.83 \pm 0.15$ \\
Ginger & $10.80 \pm 0.27$ & $12.40 \pm 0.10$ & $15.33 \pm 0.21$ & $16.33 \pm 0.21$ \\
Sembung & $8.63 \pm 0.32$ & $9.57 \pm 0.25$ & $10.40 \pm 0.10$ & $11.63 \pm 0.21$ \\
\hline
\end{tabular}

Table 4: Diameter of inhibitory zone from all extracts against Microsporum gypseum

\begin{tabular}{lllll}
\hline \multirow{2}{*}{ Extract } & \multicolumn{4}{l}{ Inhibitory zone $(\mathbf{m m})$} \\
\cline { 2 - 5 } & $\mathbf{2 \%}$ & $\mathbf{4 \%}$ & $\mathbf{6 \%}$ & $\mathbf{8 \%}$ \\
\hline Rosemary & - & $7.60 \pm 0.27$ & $9.07 \pm 0.15$ & $10.13 \pm 0.21$ \\
Java turmeric & $11.40 \pm 0.1$ & $12.87 \pm 0.21$ & $14.57 \pm 0.15$ & $16.50 \pm 0.36$ \\
Beluntas & - & - & $7.40 \pm 0.20$ & $8.97 \pm 0.15$ \\
Lengkeng & - & - & - & $7.77 \pm 0.15$ \\
Ginger & $10.10 \pm 0.27$ & $11.87 \pm 0.15$ & $13.63 \pm 0.30$ & $15.20 \pm 0.20$ \\
Sembung & - & - & $7.80 \pm 0.26$ & $9.07 \pm 0.15$ \\
\hline
\end{tabular}

Table 5: Antifungal interaction between extracts against Trichophyton mentagrophytes

\begin{tabular}{llll}
\hline Extract 1 & Extract 2 & Extract 3 & Type of interaction \\
\hline Java turmeric & Ginger & & Synergistic \\
Java turmeric & Rosemary & & Synergistic \\
Ginger & Rosemary & & Synergistic \\
Java turmeric & Lengkeng & & Additive \\
Ginger & Lengkeng & & Additive \\
Java turmeric & Sembung & & Synergistic \\
Ginger & Sembung & & Synergistic \\
Java turmeric & Beluntas & & Additive \\
Ginger & Beluntas & & Synergistic \\
Java turmeric & Ginger & Rosemary & Synergistic \\
Java turmeric & Ginger & Lengkeng & Additive \\
Java turmeric & Ginger & Sembung & Synergistic \\
Java turmeric & Ginger & Beluntas & Additive \\
\hline
\end{tabular}

\section{Fractionation}

Combination of extracts resulting in synergistic effect on this study was Java turmeric rhizome, ginger rhizome, and rosemary leaves. These extracts were then fractionated using liquid-liquid extraction
Table 6: Antifungal Interaction between extracts against Microsporum gypseum

\begin{tabular}{llll}
\hline Extract 1 & Extract 2 & Extract 3 & Type of interaction \\
\hline Java turmeric & Ginger & & Additive \\
Java turmeric & Rosemary & & Additive \\
Ginger & Rosemary & & Additive \\
Java turmeric & Lengkeng & & Additive \\
Ginger & Lengkeng & & Additive \\
Java turmeric & Sembung & & Additive \\
Ginger & Sembung & & Additive \\
Java turmeric & Beluntas & & Additive \\
Ginger & Beluntas & & Synergistic \\
Java turmeric & Ginger & Rosemary & Additive \\
Java turmeric & Ginger & Lengkeng & Additive \\
Java turmeric & Ginger & Sembung & Additive \\
Java turmeric & Ginger & Beluntas & Additive \\
\hline
\end{tabular}

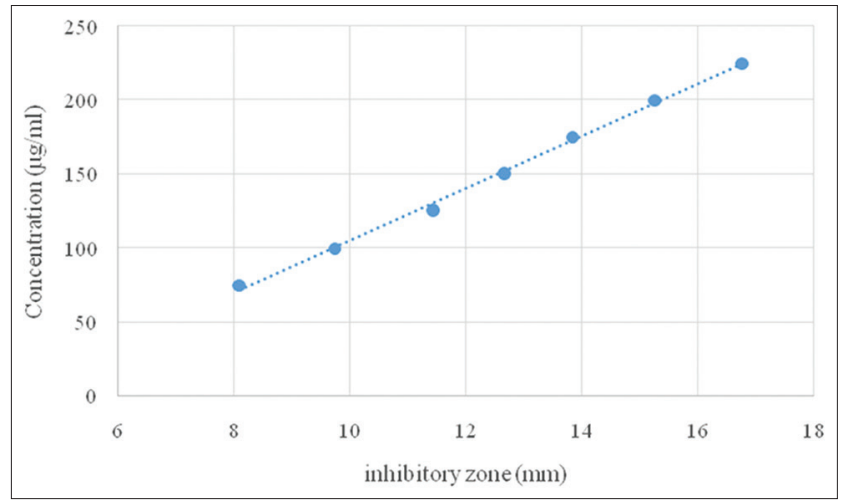

Fig. 3: Calibration curve of ketoconazole. Linear equation is $y=17.676 x-25.62, R^{2}=0.984$

by subsequent solvents: N-hexane and ethyl acetate. The process was followed by determination of chromatogram and the yield of fraction (Table 7) and MIC-MFC determination (Table 7).

Potential equivalence toward ketoconazole

Antifungal potency was determined by comparing the activity of extracts and fractions to ketoconazole. Obtained result of this experiment is shown in Table 8 utilizing calibration curve which is presented in Fig. 3.

Using an equation depicted in Fig. 3, the highest equivalence was shown is Java turmeric extract among remained extract. Approximately $1 \mathrm{mg}$ of Java turmeric extract equivalent to $0.0071 \mathrm{mg}$ ketoconazole. Otherwise, 
Table 7: Yield of fraction over the extract

\begin{tabular}{|c|c|c|c|c|c|c|}
\hline \multirow[t]{2}{*}{ Extract } & \multirow[t]{2}{*}{ Fraction } & \multirow[t]{2}{*}{$\%$ yield } & \multicolumn{2}{|c|}{ Trichophyton mentagrophytes } & \multicolumn{2}{|c|}{ Microsporum gypseum } \\
\hline & & & MIC $(\mu \mathrm{g} / \mathrm{mL})$ & MFC $(\mu \mathrm{g} / \mathrm{mL})$ & MIC $(\mu \mathrm{g} / \mathrm{mL})$ & MFC $(\mu \mathrm{g} / \mathrm{mL})$ \\
\hline \multirow[t]{2}{*}{ Java turmeric rhizome } & Water & 45.23 & 2048 & $>4096$ & 2048 & $>4096$ \\
\hline & N-hexane & 1.78 & 128 & 1024 & 64 & 1024 \\
\hline \multirow[t]{3}{*}{ Ginger rhizome } & Water & 25.28 & - & - & - & - \\
\hline & Ethyl acetate & 10.11 & 64 & 512 & 256 & 1024 \\
\hline & N-hexane & 1.78 & 128 & 1024 & 256 & 1024 \\
\hline \multirow[t]{3}{*}{ Rosemary leaves } & Water & 21.67 & 1024 & $>4096$ & 1024 & $>4096$ \\
\hline & Ethyl acetate & 4.72 & 1024 & $>4096$ & - & - \\
\hline & N-hexane & 2.02 & 128 & 512 & 512 & $>4096$ \\
\hline
\end{tabular}

MIC: Minimum inhibitory concentration, MFC: Minimum fungicidal concentration

Table 8: Equivalence potency of tested substances

\begin{tabular}{|c|c|c|c|}
\hline Tested substances & Sample concentration (ppm) & Ketoconazole concentration (ppm) & $\begin{array}{l}\text { Equivalence of } 1 \text { mg substance } \\
\text { toward ketoconazole } \times \mathrm{mg} \text { ) }\end{array}$ \\
\hline Java turmeric extract & 20,000 & 144.12 & 0.00701 \\
\hline Ginger extract & 40,000 & 144.43 & 0.00361 \\
\hline Rosemary extract & 50,000 & 140.73 & 0.00282 \\
\hline $\mathrm{N}$-hexane fraction of Java turmeric & 10,000 & 110.48 & 0.01105 \\
\hline Ethyl acetate fraction of rosemary & 10,000 & 129.63 & 0.01296 \\
\hline $\mathrm{N}$-hexane fraction of ginger & 10,000 & 148.86 & 0.01489 \\
\hline
\end{tabular}
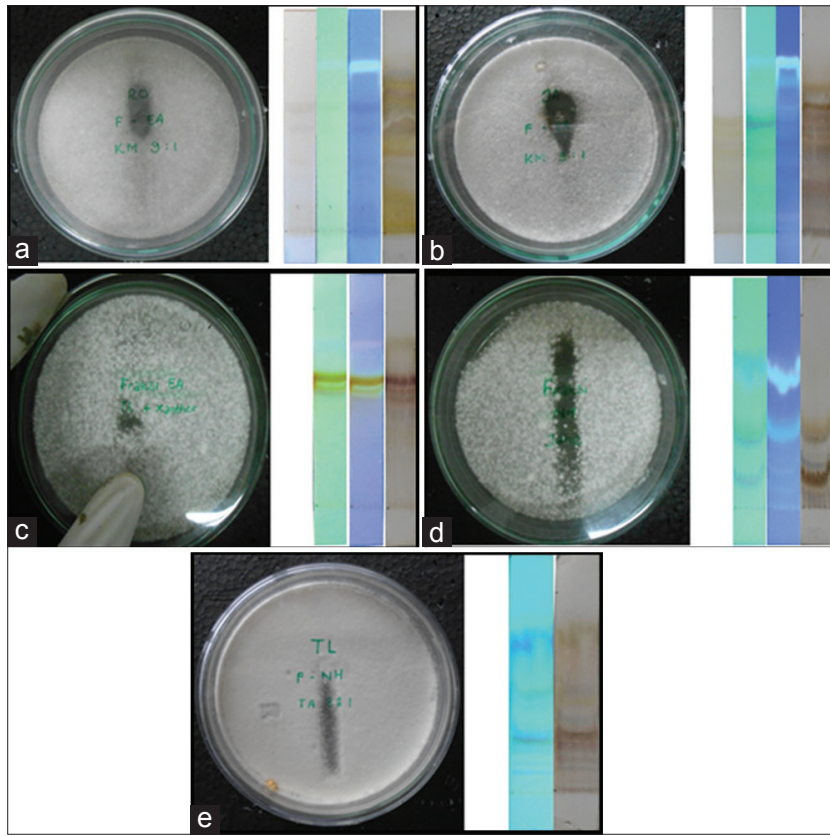

Fig. 4: Ethyl acetate fraction of rosemary (a), ginger (b), Java turmeric (c), n-hexane fraction of ginger (d), Java turmeric (e). Al samples were evaluated through bioautography using silica gel GF254 as stationary phase, mixture of chloroform-methanol (9:1) plus 4 drops of acetic acid ( $a$ and $b$ ), toluene-acetone (8:1) plus 4 drops acetic acid (c), toluene-acetone (9:1) plus 4 drops acetic acid

the highest potency was possessed by $\mathrm{n}$-hexane fraction of ginger $(1 \mathrm{mg}$ fraction $\sim 0.01489 \mathrm{mg}$ ketoconazole)

There are some limitations to determine inhibitory zone using agar diffusion, especially when the substances are extracted by organic solvents. Almost all extracted matters are considerably non-polar or semi-polar. Nevertheless, water is the main solvent in the media and it may prevent the less polar compounds to diffuse. A highly deviation though measurement is one of the limitations of this protocol.

\section{Bioautography TLC}

Bioautography TLC from selected fraction was performed by direct contact to T. mentagrophytes. The aims of this method were to determine active compounds possessing antifungal activity by comparing its $\mathrm{Rf}$ and its inhibitory zone on the chromatogram.

Based on the results, there were 3 components from ethyl acetate of rosemary inhibited T. mentagrophytes, meanwhile 5 components from ethyl acetate of ginger inhibited the same fungi. $\mathrm{N}$-hexane fraction of Java turmeric and n-hexane fraction of ginger showed 6 and 4 components, respectively, actively inhibited the corresponding fungi (Fig. 4).

\section{CONCLUSION}

Ethanolic extract of rosemary leaves, ginger rhizome, and Java turmeric rhizome in combination showed the highest potency and synergistic effect when it was combined against T. mentagrophytes. There are several compounds in each extract that possessed antifungal effect through bioautography TLC.

\section{REFERENCES}

1. Nasution MA. Miycology and medical micology: Dermatology point of view. Scientific Speech in Medical Dermatology in Faculty of Medicine. Medan: Universitas Sumatera Utara; 2006.

2. Kurniati CR. Ethiopathogenesis of dermatophytosis. Berkala Ilmu Kesehatan Kulit and Kelamin 2008:20;243-50.

3. Adiguna MS. Epidemiology of Dermatomycosis in Indonesia 2004. $3^{\text {rd }}$ ed. Jakarta: Balai Penerbit FK UI; 2006.

4. Cragg GM, Newman DJ. Medicinals for the millennia: The historical record. Ann N Y Acad Sci 2001;953:3-25.

5. WHO. Quality Control methods for Medicinal Plant Materials. Geneva: WHO Library Cataloguing in Publication Data; 1998.

6. Power DA, Peggy JM. Manual of BBL Products and Laboratory Procedures. $6^{\text {th }}$ ed. New York: Becton Dickinson and Co.; 1988.

7. Tereschuk ML, Riera MV, Castro GR, Abdala LR. Antimicrobial activity of flavonoids from leaves of Tagetes minuta. J Ethnopharmacol 1997;56(3):227-32.

8. NCCLS. Reference Method for Broth Dilution Antifungal Susceptibility Testing of Yeasts; Approved Standard. $2^{\text {nd }}$ ed. USA: NCCLS Document M27-A2; 2002.

9. Santos DA, Barros ME, Hamdan JS. Established a method of inoculum preparation for susceptibility testing of Trichophyton rubrum and Trichophyton mentagrophytes. J Clin Microbiol 2006;44:98-101. 
10. Rukayadi Y, Hwang JK. In vitro antimycotic activity of xanthorrhizol isolated from Curcuma xanthorrhiza Roxb. against opportunistic filamentous fungi. Phytother Res 2007;21(5):434-8.

11. Rand KH, Houck HJ, Brown P, Bennett D. Reproducibility of the microdilution checkerboard method for antibiotic synergy. Antimicrob Agents Chemother 1993;37(3):613-5.

12. Widodo GP. Isolation of Active Component and Its Mechanism of Action from Daun Babadotan (Ageratum conyzoides L.), Doctoral Dissertation, School of Pharmacy, ITB. Bandung: Institut Teknologi Bandung; 2008

13. Gangwar KK, Deepali GR, Gangwar RS. Ethnomedicinal plant diversity in Kumaun himalaya of Uttarakhand, India. Nat Sci 2010;8(5):66-78.

14. Gairola S, Shariff NM, Bhatt A. Influence of climate change on production of secondary chemicals in high altitude medicinal plants: Issues needs immediate attention. J Med Plants Res 2010;4(18):1825-9.

15. Frankel EN, Huang SW, Aeschbach R, Prior E. Antioxidant activity of a rosemary extract and its constituents, carnosic acid, carnosol, and rosmarinic acid, in bulk oil and oil-in-water emulsion. J Agric Food Chem 1996;44(1):131-5

16. Valera MC, Maekawa LE, Chung A, Cardoso FG, Oliveira LD, Oliveira CL, et al. The effect of sodium hypochlorite and ginger extract on microorganisms and endotoxins in endodontic treatment of infected root canals. General Dent 2013;62(3):25-9.

17. Azizi A, Aghayan S, Zaker S, Shakeri M, Entezari N, Lawaf S. In vitro effect of Zingiber officinale extract on growth of Streptococcus mutans and Streptococcus sanguinis. Int J Dent 2015;2015:489842.

18. Ebrahimzadeh Attari V, Ostadrahimi A, Asghari Jafarabadi M,
Mehralizadeh S, Mahluji S. Changes of serum adipocytokines and body weight following Zingiber officinale supplementation in obese women: A RCT. Eur J Nutr 2016;55(6):2129-36.

19. Marx W, McKavanagh D, McCarthy AL, Bird R, Ried K, Chan A. The effect of Ginger (Zingiber officinale) on platelet aggregation: A systematic literature review. PLoS One 2015;10(10):e0141119.

20. Kazeem MI, Akanji MA, Yakubu MT. Amelioration of pancreatic and renal derangements in streptozotocin-induced diabetic rats by polyphenol extracts of Ginger (Zingiber officinale) rhizome. Pathophysiology 2015;22(4):203-9.

21. Wilson PB. Ginger (Zingiber officinale) as an analgesic and ergogenic aid in sport: A systemic review. J Strength Cond Res 2015;29(10):2980-95

22. Cojocaru SI, Stan M, Stoian G, Dinischiotu A. Effects of Zingiber officinale roscoe fresh extract on amelanotic melanoma and normal skin fibroblasts. Rev Med Chir Soc Med Nat Iasi 2015;119(2):592-6.

23. Li Y, Tran VH, Duke CC, Roufogalis BD. Gingerols of Zingiber officinale enhance glucose uptake by increasing cell surface GLUT4 in cultured L6 myotubes. Planta Med 2012;78(14):1549-55.

24. Halim MR, Marina SM, Sabariah I, Roziahanim M. Standardization and Phytochemical studies of Curcuma xanthorrhiza Roxb. IJPPS 2012;4(3):606-10.

25. Kim AJ, Kim YO, Shim JS, Hwang JK. Immunostimulating activity of crude polysaccharide extract isolated from Curcuma xanthorrhiza Roxb. Biosci Biotechnol Biochem 2007;71(6):1428-38.

26. Lorian V. Antibiotics in Laboratory Medicine. $5^{\text {th }}$ ed. London: Williams and Wilkins; 2005. 